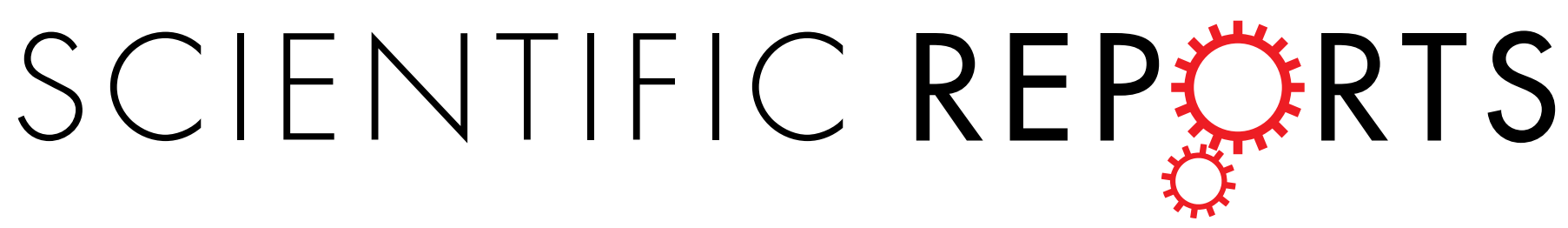

\title{
OPEN Erratum: An exactly solvable, spatial model of mutation accumulation in cancer
}

\author{
Chay Paterson, Martin A. Nowak \& Bartlomiej Waclaw
}

Scientific Reports 6:39511; doi: 10.1038/srep39511; 22 December 2016; updated on 20 October 2017

A Supplementary Information data file and Supplementary Mathematica notebook file were omitted from the original version of this Article. This has been corrected in the PDF and HTML version of the Article.

(c) (i) This work is licensed under a Creative Commons Attribution 4.0 International License. The images or other third party material in this article are included in the article's Creative Commons license, unless indicated otherwise in the credit line; if the material is not included under the Creative Commons license, users will need to obtain permission from the license holder to reproduce the material. To view a copy of this license, visit http://creativecommons.org/licenses/by/4.0/

(c) The Author(s) 2017 